\title{
Factors Affecting African-American Health: Empowering the Community with Health Literacy
}

Anita Mandal, Judy Scott, Noor K. Islam and Prabir K. Mandal*

Edward Waters College, 1658 Kings Road, Jacksonville, FL 32209, USA

Every racial or ethnic group has specific health concerns due to genetics, environmental factors, access to care and cultural factors. Of the minority groups, African-Americans (make up about $13 \%$ of the U.S. population) have the most. The most common health issues for African-Americans include high blood pressure, obesity, diabetes, stroke, kidney failure and cancer.

Despite improvements in the overall health of Americans, minorities, primarily African Americans tend to have more chronic health problems, live in poverty, lack insurance coverage, and be unable to work because of a disability [1]. These disparities are multi-variant. Contributing factors include socioeconomic status (SES: education, employment and income), poor health literacy, and lifestyle behaviors (physical activity, substance abuse etc.). Heart disease and cancer are the first and second leading causes of death for African-American adults 18 years and older. Stroke and diabetes were the third and fourth leading cause of death among African-American adults 18 years and older during 2002 [2]. When dining out, fast food was the most popular restaurant choice among African Americans (29\%), casual sit-down restaurants ranked second (26\%), and soul food establishments came in third (22\%). African Americans eating at fast food restaurants most often ate significantly fewer fruits and vegetables. However, there were no differences in fruit and vegetable intake when eating at other types of dining establishments [3]. Fast food consumption is associated with a diet high in energy (calories), low in essential micronutrients. Frequent fast food consumption may contribute to weight gain, because fast foods can provide more than one-third of the day's energy, total fat and saturated fat. Negligible amounts of milk and fruits and large amounts of non-diet carbonated soft drinks tend to be consumed at fast food places. Also, adults who report eating fast food regularly tend to have higher mean body mass index (BMI) values than those who did not eat fast food [4].

In 2009, health care spending in the U.S. reached $\$ 2.5$ trillion or $\$ 8,086$ per person [5]. Despite this tremendous expenditure, it is well documented that ethnic and racial minorities are disproportionately affected by many health conditions that negatively impact their health in comparison to White Americans. While the causes associated with disparities in health and health care are varied, it is important to understand the role socioeconomic status plays in health status. Lower socioeconomic status often results in inadequate housing; poor nutrition; bad social environments, and working conditions; poor access to or limited contact with the health care system; and fewer social amenities that directly or indirectly affect health. The impact of lower socioeconomic status on morbidity and mortality is especially pronounced among African Americans [6]. African Americans have one of the highest levels of obesity in the U.S. 58\% of African American men and 69\% of African American women are either overweight or obese [7]. Being overweight can make you 2-6 times more likely to develop high blood pressure than if you are at your desirable weight. Increasing numbers of African Americans suffer from health problems associated with obesity, such as high cholesterol, stroke, hypertension, asthma, sleep apnea, polycystic ovarian syndrome, and orthopedic problems. The highest rates of diabetes are found among black women-one in four women over 55 years of age has diabetes. African Americans also have higher rates of complications from diabetes, such as blindness, cardiovascular disease, end stage renal disease (kidney disease) and amputation [8] According to the American Heart Association, cardiovascular disease (CVD) ranks as the number one killer of African Americans, claiming the lives of 36\% of the more than 290,000 African Americans who die each year. It was also reported that the rate of high blood pressure in African Americans in the U.S. is among the highest in the world [9].

In an attempt to eliminate health disparities among minority populations, in 2002, the United States Department of Health and Human Services (HHS) created an educational campaign designed to help make good health an important issue among racial and ethnic minority populations. The campaign Closing the Health Gap supports HHS' efforts to eliminate racial and ethnic health disparities and promote the goals of Healthy People 2010. It also advances the HHS Steps to a Healthier U.S. program and the President's Healthier U.S. Initiative [2]. In order to help improve the health status of African Americans, the gap in racial and ethnic disparities in health care must be addressed. The Institute of Medicine (IOM) report, Unequal Treatment: Confronting Racial and Ethnic Disparities in Care, provides compelling evidence that racial and ethnic disparities persist in medical care for a number of health conditions and services. These disparities exist even when comparing individuals of similar income and insurance coverage [10]. African Americans show higher susceptibility to various types of cancer and cardiac abnormalities. The rate of smoking is historically higher in African Americans when compared to the general US population. Smoking related diseases kill approximately 45,000 African American each year. Heart diseases account for more deaths (27\%) in African Americans when compared to deaths due to all forms of cancer (21\%). A decrease in plasma levels of glutamate and increase in serotonin, epinephrine and dopamine were reported in smokers. Smoking behavior further increases the chances of disease manifestation [11], as it raises the blood pressure making the heart work harder to maintain the blood flow. The AfricanAmerican community is traditionally based on family, sharing, and cooperation. Many of the traditional ways of sharing and interacting center on food which are typically high in fat and high in calories. African Americans tend to focus less on the health consequences of

*Corresponding author: Prabir K. Mandal, Edward Waters College, 1658 Kings Road, Jacksonville, FL 32209, USA, Tel: (904) 470-8091; Fax: (904) 470-8047; Email: prabir.mandal0807@ewc.edu

Received January 25, 2013; Accepted January 27, 2013; Published February 05, 2013

Citation: Mandal A, Scott J, Islam NK, Mandal PK (2013) Factors Affecting AfricanAmerican Health: Empowering the Community with Health Literacy. J Bioprocess Biotech 3:e111 doi: 10.4172/2155-9821.1000e111

Copyright: ( 2013 Mandal A, et al. This is an open-access article distributed unde the terms of the Creative Commons Attribution License, which permits unrestricted use, distribution, and reproduction in any medium, provided the original author and source are credited. 
Citation: Mandal A, Scott J, Islam NK, Mandal PK (2013) Factors Affecting African-American Health: Empowering the Community with Health Literacy. J Bioprocess Biotech 3:e111 doi: 10.4172/2155-9821.1000e111

what is being eaten and more on simply enjoying the company and emotional support of friends and family.

Your body is made up of trillions of cells that live mostly for a few weeks or month, die and are replaced by new cells. For example, your taste buds live only a few hours, white blood cells live 10 days, and your muscle cells live about three months. These cells are in a constant state of renewal. So what do you need to do to be as healthy as you can? Eat more fruits and vegetables and eat fewer saturated fat and fried foods, salt and processed foods. Choose good nutritious meals rather than eating out, can help you stay on the road to good health. It is very important to know your family health history and share it with other family members and develop strategies for better lifestyles e.g., making wise food choice, engage in consistent physical activities and managing stress.

\section{Reference}

1. National Center for Health Statistics (2005) With Chartbook on Trends in the Health of Americans. Hyattsville, Maryland, USA.

2. US Department of Health and Human Services (2006) Closing the Health Gap, Fact Sheet.

3. Network for a Healthy California-African American Campaign, California Department of Public Health, California, USA.
4. Bowman SA, Vinyard BT (2004) Fast food consumption of U.S. adults: impact on energy and nutrient intakes and overweight status. J Am Coll Nutr 23 163-168.

5. Martin A, Lassman D, Whittle L, Catlin A, National Health Expenditure Accounts Team (2011) Recession contributes to slowest annual rate of increase in health spending in five decades. Health Aff (Millwood) 30: 11-22.

6. Office of Minority Health, Office of the Director, CDC (2005) Health Disparities Experienced by Black or African Americans-United States. MMWR 54: 1-3.

7. Prevalence of Overweight and Obesity among Adults 1999-2000. Table 70 (2002). Healthy weight, overweight, and obesity among persons 20 years of age and over, according to sex, age, race, and Hispanic origin: United States, 1960-62, 1971-74, 1976-80, 1988-94, and 1999-2000, Table 70. NCHS. Hyattsville, MD: National Center for Health and Statistics.

8. U.S. Department of Health and Human (2006) Overweight and Obesity Statistics, Weight-control Information Network, National Institutes of Health, USA.

9. American Heart Association (2005) High Blood Pressure and African Americans.

10. Collins KSt, Tenney K, Hughes DL (2002) Quality of Health Care for African Americans Findings from the Commonwealth Fund 2001 Health Care Quality Survey. The Commonwealth Fund

11. Mishra S, Mandal A, Mandal PK (2011) Smoking Related Changes in Neurotransmitters in African Americans. J Bioproces Biotechniq 1: e106. 